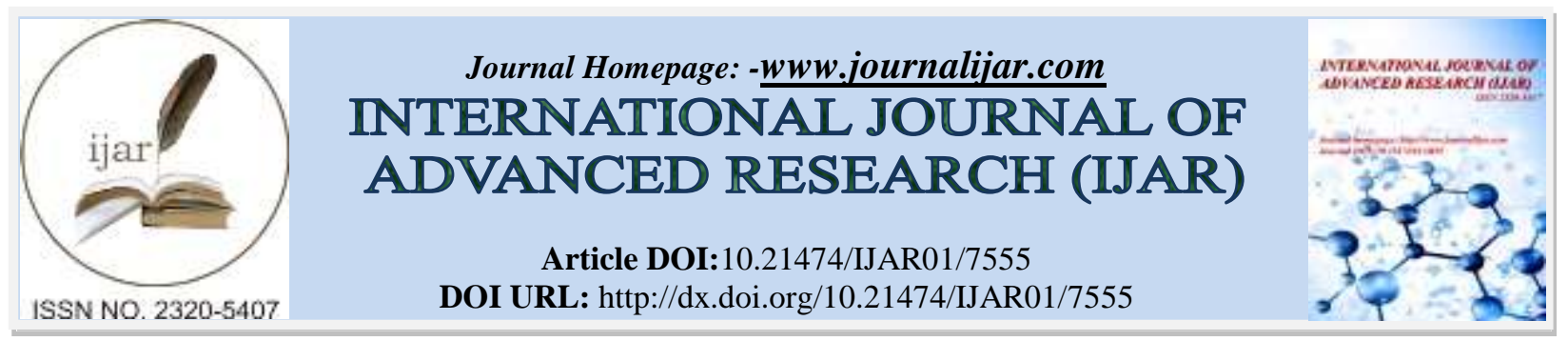

RESEARCH ARTICLE

\title{
Trapa natans L. (WATER CHESTNUT) IN HIMALAYAN WETLAND DEORIA TAL, INDIA.
}

\author{
Sheetal Chaudhary ${ }^{1}$ and Dinesh Kumar ${ }^{2}$. \\ 1. Department of Environmental Sciences, Hemwati Nandan Bahuguna Garhwal University (A Central \\ University), Srinagar Garhwal- 246174, Uttarakhand, India. \\ 2. Head, School of Agriculture, Himalayan College, Roorkee Institute of Technology, Puhana, Roorkee- \\ 247667, India.
}

\section{Manuscript Info}

\section{Manuscript History}

Received: 13 June 2018

Final Accepted: 15 July 2018

Published: August 2018

Keywords:-

Wetland, Trapa, Garhwal Himalaya, Deoria Tal, Management.

\begin{abstract}
The Himalayas are the rich source of tangible and intangible goods and services. The Himalayan lakes and wetlands possess rich and diverse biodiversity. The present study was conducted to find the impacts of Trapa natans (water chestnut) on Himalayan wetland Deoria Tal from April 2014- March 2016 spreading in the epilimnetic zone of the wetland. The beautiful wetland is a tourist spot and is famous for its landscape and panoramic view of the nearby snowy mountain peaks that are reflected in the water, which are the main attraction for the tourists round the year. Water chestnut hinders the picturesque beauty as well as the path of aquatic fauna. Keeping in view the effects of water chestnut on the wetland, few objectives and control measures have been suggested for its eradication so that conservation and management should be done.
\end{abstract}

Copy Right, IJAR, 2018,. All rights reserved.

\section{Introduction:-}

Deoria Tal is a beautiful wetland located at an altitude of $2,445 \mathrm{~m}$ above m.s.l. between latitude $30^{\circ} 31^{\prime} 44^{\prime \prime} \mathrm{N}$ and longitude $79^{\circ} 07^{\prime} 48^{\prime \prime}$ E to South-East of Ukhimath in the Rudraprayag district of Garhwal Himalaya, India with an area of $25,703.06 \mathrm{~m}^{2}$, covering total circumference of $759.62 \mathrm{~m}$ (Fig 1). The wetland is 12 kilometers from Ukhimath through village Sari. From Sari, there is a trek route of $3 \mathrm{~km}$ towards the wetland. It has so many mythical stories connected with the epic "Mahabharata". Local people believe it pure and sacred as devas (Hindu Gods) bathe in the water so the name given "Devarial Devariyal Deoria" and celebrate the festival "Krishna Janamashtami" on $15^{\text {th }}$ September every year in which a huge crowd gathers near the wetland and do Nagaraja (God of Snakes) puja (Sharma et al, 2018).

The wetland is facing a serious problem of weed Trapa natans from the last few years. This weed is commonly known as water chestnut/ horned water chestnut/ water caltrop/ water nut/ bull nut that dominate shallow lakes, ponds and river margins (Pemberton, 1995) and is an invasive annual macrophyte that grows mainly in parts of southern Europe, Africa, Asia and spread worldwide. It has been grown in Europe and used as food by ancient Europeans (Bhatwal et al., 2012). Historically, the herb was used as an ornamental herb. Every year, tourists visit the place and attracted towards the scenic beauty and landscape (Fig 2). Wetlands help in maintaining the natural cycles and ecological diversity so the present study is focused to provide very first report on the impact of the weed on the wetland. Tantary and Rafiq, 2013 discussed the effect of nutrient concentration on biochemical characteristics of Trapa natans in Mansbal lake, Kashmir. Adkar et. al., 2014 discussed nutritional and 
pharmacological aspects of Trapa bispinosa. Few Gani et. al., 2010 examined Physico-chemical, morphological and pasting properties of starches from water Chestnuts from three Lakes of Kashmir, India. Few research articles have been published on the water quality and microbiological diversity of Deoria Tal (Sharma et. al., 2018; Chaudhary et. al., 2018). It has become important to control or keep a check on the weed Trapa natans so that the beauty, as well as the water quality will remain in the actual state.

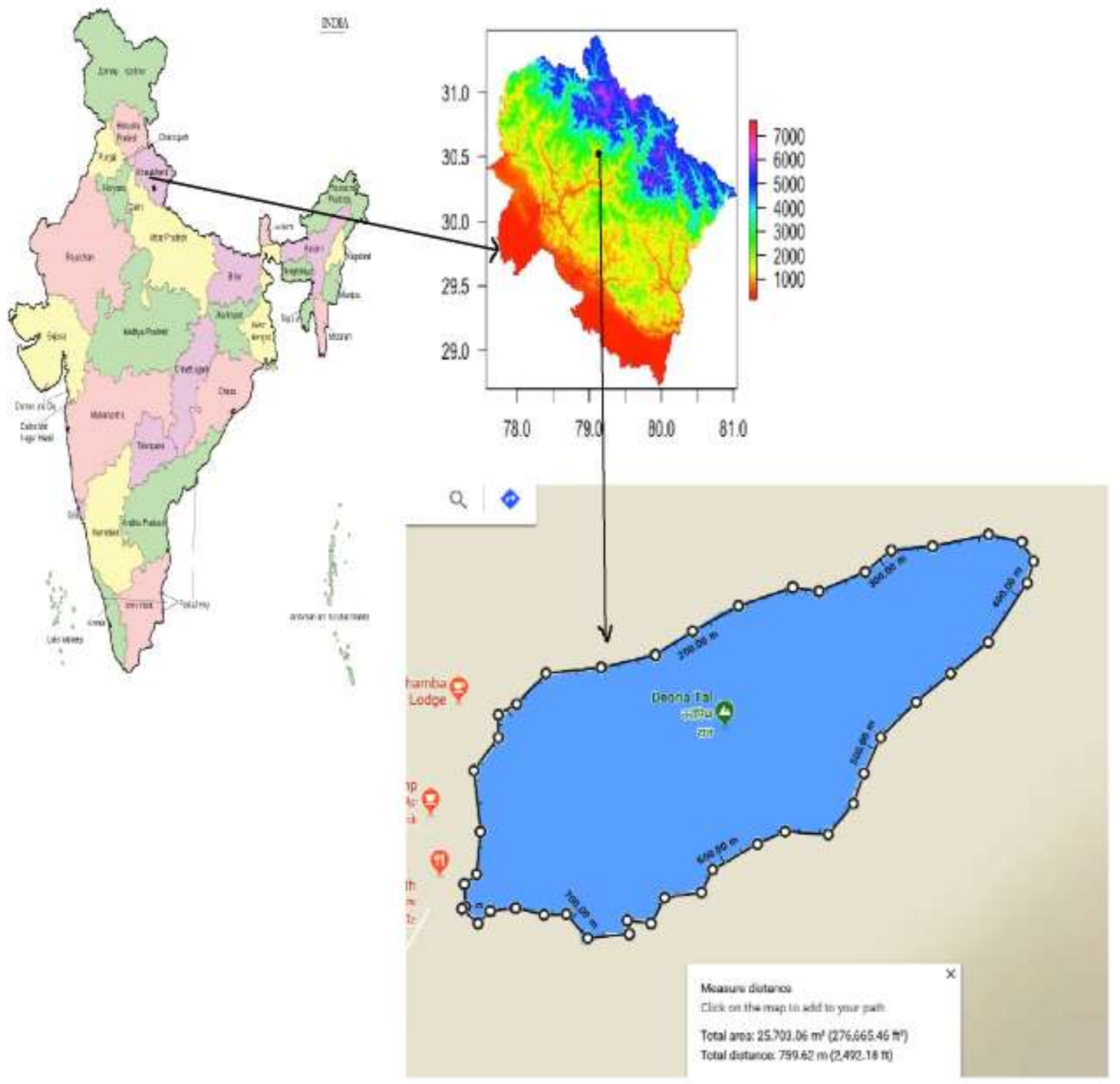

Figure 1:- Map of the Wetland Deoria Tal, India (Source: Google Earth) 


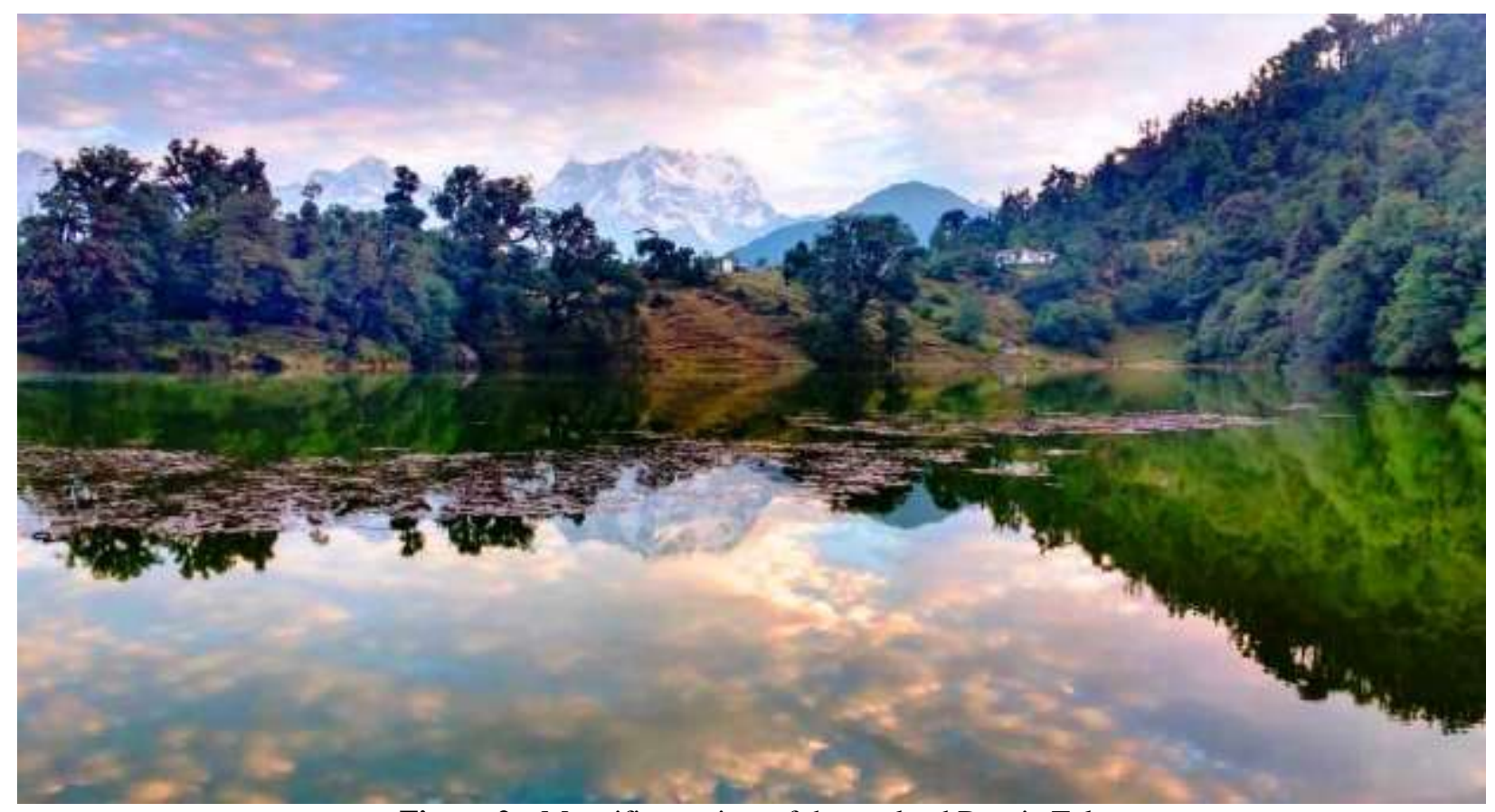

Figure 2:- Magnificent view of the wetland Deoria Tal

Description of the plant:-

Trapa natans L. (Family: Trapaceae) is an annual, broadleaved and herbaceous freshwater macrophytic weed having slender roots that grows from the bottom with annual reproductive cycles. The persistent seeds usually germinate in the spring season. This macrophyte has a floating canopy of leaves with a submerged stem (Hummel and Kiviat, 2004). The leaves petiole float on the surface of the water. The stems have many branched roots. The plant has single white and small flowers that grow in the center of the rosette. Each rosette can produce hard, nut-like and sharp spiny fruits in July. T. natans grows best in shallow and nutrient-rich water bodies with a $\mathrm{pH}$ range of 6.7-8.2 and calcium carbonate alkalinity of 12-128 mg/l (Charles, 2006) When the fruit with older leaves is released from the parent plant, the central terminal meristem produces new leaves in the rosette (Groth et al, 1996). The plant spread in the shallow water bodies at a very fast rate, deteriorating the health of the aquatic ecosystem.

Plant Physiology Timeline
- Mid-May: central rosettes emerge from the water
- Mid-June: secondary rosettes emerge, central rosettes forming flowers
Early July: secondary rosettes flowering, mature seeds already viable on central rosettes
Late July: hundreds of viable seeds present on each plant
Source: Maryland Department of Natural Resources Management Strategies
for Water Chestnut (Trapa natans): A Historical Perspective

Impact of Trapa natans on wetland:-

Wetland Deoria Tal is blessed with a beautiful panoramic view. The reflecting images of the nearby mountain peaks like Chaukhamba, Nilkantha, Kalanag and Bandarpunch can be seen in the crystal clear water of the wetland (Fig 2). T. natans not only forms the nuisance mat over the surface of the water, but block the reflection of the snowy peaks and vegetation. These mats affect aquatic ecosystems by obstructing the path of the aquatic fauna. The spiny nuts can create injuries to people and cattle walking along the shore of the wetland. The mats of $T$. natans can affect the productivity cycles of the wetland as well as the water quality by decreasing the dissolved oxygen because of the decomposition of the plant in the water. The growing population can also affect the light penetration path of the phytoplankton. In Hudson's river study, 0.5\% light could reach underneath beds of T. natans (Caraco and Cole, 2002). Hummel and Kiviat, 2004 also reported intercept $95 \%$ of light. 


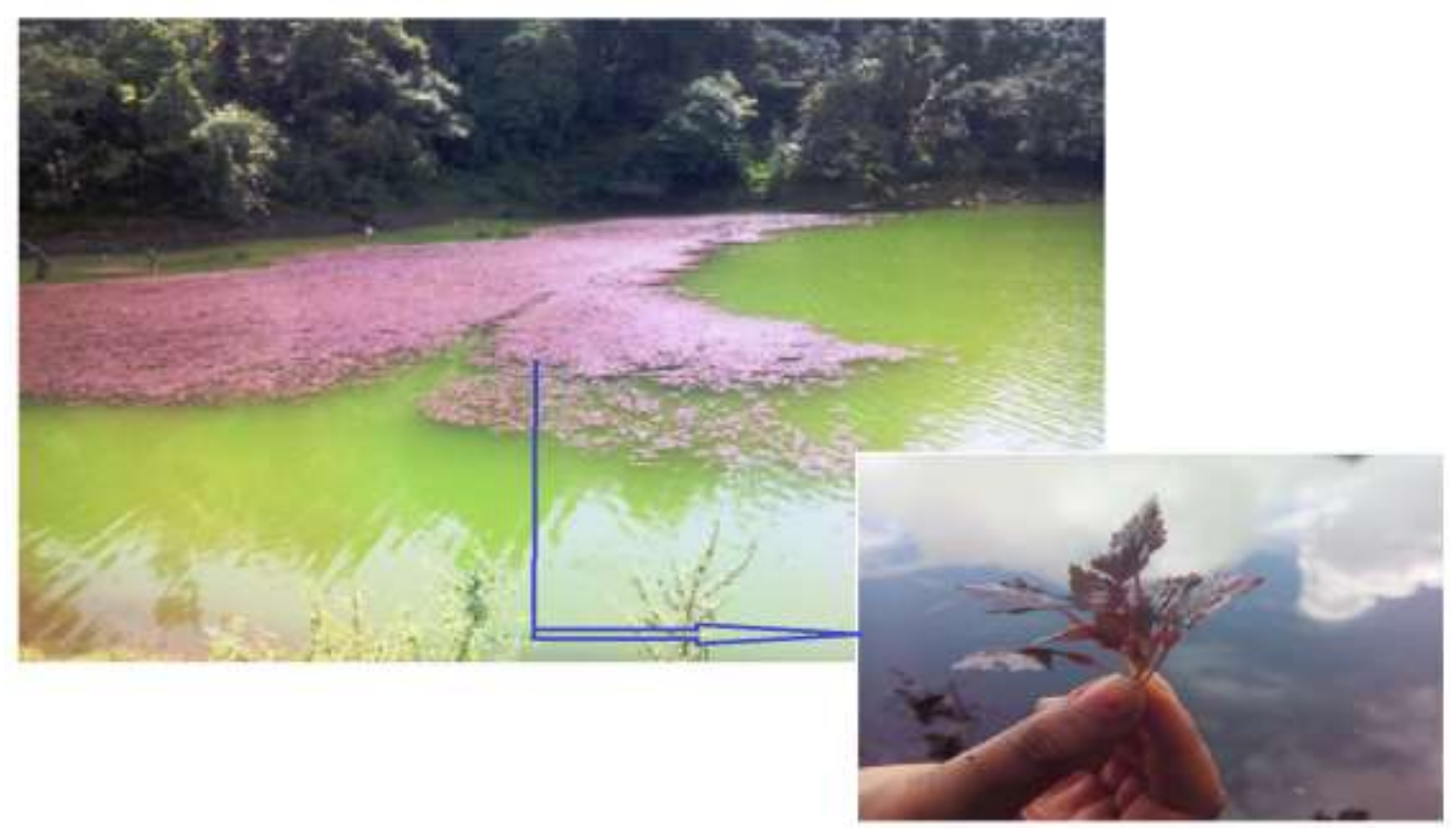

Figure 3:- Trapa natans (Water chestnut) mat affecting the wetland Deoria Tal

\section{Conservation and management:-}

Keeping in view the significant role of wetlands, it is important to take the initiatives for better conservation of the Himalayan wetland Deoria Tal and find suitable measures for its management.

The complete eradication of $T$. natans is not possible because of its fast growing nature. The process requires expensive control efforts. Few following measures have been suggested for the removal of species from the wetland.

\section{Harvesting-}

Hand harvesting is a good option to remove the small plants (Naylor, 2003). All plants can be removed to minimize the expanding population of T. natans (Swearingen et al, 2010). The harvested fragments of weed should be disposed off at a place far from the wetland. Harvesting should be done before the abscission and maturation of seeds (Methe et al, 1993). As the seeds remain present for many years, sequential harvesting should be done for complete and effective eradication (Naylor, 2003; Hunt and Marangelo, 2009).

\section{Biological:-}

The leaf beetle Galerucella birmanica has remarkable negative impacts on T. natans populations and is used as pest in China (Ding et al, 2006).

Chemical

Herbicides containing 2,4-D are effective in controlling T. natans and provide best results in early summer. 2, 4-D. Herbicides containing triclopyr are also effective but their use may harm other plants. The growth can also be repressed by light attenuating dyes before the plant germination.

\section{Conclusion:-}

T. natans, an indigenous weed is posing a threat to the Himalayan wetland Deoria Tal. Few measures have been suggested for the eradication of the weed. The forest department and the local agencies should come up with the best solution measures for its conservation and management. As this plant has some medicinal properties too, the awareness campaigns should be organized for the local people to make them aware of the use as well as effects.

\section{Conflict of interest:-}

There is no conflict of interest regarding the publication of this paper. 


\section{Acknowledgement:-}

I would like to acknowledge the University Grants Commission (UGC) and Hemwati Nandan Bahuguna Garhwal University (A Central University), Srinagar Garhwal, Uttarakhand, India for providing the Central University Fellowship from March 2013 to June 2016.

\section{References:-}

1. Adkar, P., Dongare, A., Ambavade, S. and Bhaskar, V.H. (2014): Trapa bispinosa Roxb.: A Review on Nutritional and Pharmacological Aspects. Advances in Pharmacological Sciences, pp 13. DOI: http://dx.doi.org/10.1155/2014/959830.

2. Caraco, N.F. and Cole, J.J. (2002): Contrasting impacts of a native and alien macrophyte on dissolved oxygen in a large river. Ecological Applications; 12(5):1496-1509.

3. Chaudhary, S., Sharma R. and Kumar R. (2018): Physico-chemical and microbiological assessment of surface water quality of a Himalayan wetland, Deoria Tal, India. Civil and Environmental Research, 10(5): 59-75.

4. Charles R. O'Neill, Jr. (2006): Water Chestnut (Trapa natans) in the Northeast NYSG Invasive Species Factsheet Series, 06-1, pp.1-4.

5. Ding, Jianqing., Blossey, Bernd., Du Yozhou and Zheng, Fushan, (2006): Galerucella birmanica (Coleoptera: Chrysomelidae), a promising potential biological control agent of water chestnut, Trapa natans. Biological Control, 36(1): 80-90.

6. Gani, A., haq, S., Masoodi, F.A., Broadway, A.A. and Gani, A. (2010): Physico-chemical, morphological and pasting properties of starches extracted from water Chestnuts (Trapa natans) from three Lakes of Kashmir, India. Brazilian Archives of Biology and Technology, 53(3): 731-740.

7. Groth, A. T., Lovett-Doust, L., and Lovett-Doust, J. (1996): Population density and module demography in Trapa natans (Trapaceae), an annual, clonal aquatic macrophyte. American Journal of Botany, 83: 1406-1415.

8. Hummel, M. and E. Kiviat (2004): Review of world literature on water chestnut with implications for management in North America. Journal of Aquatic Plant Management, 42: 17-28.

9. Hunt, T. and Marangelo, P. (2009): Water chestnut management programs: Lake Champlain and inland Vermont waters. Lake Champlain Basin Program, pp.1-47.

10. Methe, B. A., Soracco, R. J., Madsen, J. D. and Boylen, C. W. (1993): Seed production and growth of water chestnut as influenced by cutting. Journal Aquatic Plant Management 31: 154-157.

11. Naylor, M. (2003): Water Chestnut (Trapa natans) in the Chesapeake Bay Watershed: A Regional Management Plan. Maryland Department of Natural Resources, pp. 1-35.

12. Pemberton, R. W. (1995): Water Chestnut. Invasive Plant Research Laboratory, U.S. Department of Agriculture, Agricultural Research Service, Ft. Lauderdale, Florida, United States, pp. 33-40.

13. Sharma, Ramesh C., Chaudhary, Sheetal., et al. (2018): Assessment of Physico-Chemical Parameters of Himalayan Wetland Deoria Tal. European Academic Research, 6(1): 202-212.

14. Swearingen, J., B. Slattery, K. Reshetiloff, and S. Zwicker. (2010): Plant Invaders of Mid-Atlantic Natural Areas, 4th ed. National Park Service and U.S. Fish and Wildlife Service. Washington, DC, pp. 168.

15. Tantary, M.A. and Rafiq, S. K. (2013): Effect of Nutrient Concentration on Biochemical Characteristics of Trapa natans a Macrophytic species of Mansbal Lake, Kashmir, India. Journal Of Environmental Science, Toxicology And Food Technology, 3(3): 32-37. 